\title{
FAKTOR-FAKTOR YANG MEMPENGARUHI KEMANDIRIAN DAERAH KABUPATEN TELUK BINTUNI TAHUN 2010-2015
}

\author{
Manasep Orocomna ${ }^{1}$ \\ jurnalmkd@gmail.com \\ B. Elita Bharanti ${ }^{2}$ \\ ebonifasia@yahoo.com \\ Paulus K. Allo Layuk \\ paskal967@gmail.com
}

\begin{abstract}
Economic development is an attempt to support one of national priorities, namely accelerate economic recovery and strengthen the sustainable economic development system based on the people's system. These priorities determination base on issue and facing challenges and the policy in economic development in short term and medium term as well (Propenas 2012-2014).

This study attempts to analyze the fiscal dependency level of Teluk Bintuni regency with the central government viewed from local fiscal decentralization degrees. Second, to analyze the influence of vehicle taxes on local revenue, which is regional potency to develop local fiscal independency. This research uses secondary data (time series) from year 2010 to 2014. This data analyzed in linear regression.

Based on the calculation the transfer variable (x1) shows calculated t of 3,659; the number of vehicles wheels 4 or more (x2) shows calculated t of 3,595; the number of vehicles wheels 2 (x3) shows calculated t of 4,140; and regional investment (x4) shows calculated t of 4,595; with the significance level smaller than 0,05 so it can be concluded that the variables partially free and significant impact on the local revenue Teluk Bintuni regency. The $f$ value of 23,468 $(23,468>9,12)$ with the significance of $0,000(0,000<$ 0,05 ) that can be concluded that four independent variables which are the transfer, the number of vehicles wheels 4 or more, the number of vehicles wheels 2, and investment, together affecting the local revenue of Teluk Bintuni regency. Local revenue Teluk Bintuni regency can be explained by variation of the four independent variables: the transfer, the number of vehicles wheels 4 or more, the number of vehicles wheels 2, and local investment of 96,9 percent.
\end{abstract}

Keyword: regional independency, tax, retribution, gross domestic regional product

\section{PENDAHULUAN}

Hakekat pembangunan nasional menurut Propenas adalah rencana pembangunan yang berskala nasional serta nasional serta merupakan konsekuensi dan komitmen bersama masyarakat Indonesia mengenai pencapaian visi dan misi bangsa. Dengan demikian, fungsi Propenas adalah untuk menyatukan pandangan dan derap langkah seluruh lapisan masyarakat dalam melaksanakan prioritas pembangunan selama lima tahun ke depan. (Propenas

\footnotetext{
${ }^{1}$ Alumni Mahasiswa Magister Keuangan Daerah Universitas Cenderawasih

2 Staf Dosen Jurusan IImu Manajemen Fakultas Ekonomi \& Bisnis Universitas Cenderawasih

${ }^{3}$ Staf Dosen Jurusan IImu Ekonomi Fakultas Ekonomi \& Bisnis Universitas Cenderawasih
} 
2010 - 2014).

Otonomi fiskal daerah merupakan salah satu aspek penting dari otonomi daerah secara keseluruhan, karena pengertian otonomi fiskal daerah menggambarkan kemampuan pemerintah daerah dalam meningkatkan PAD seperti pajak, retribusi dan lain-lain. Namun harus diakui bahwa derajat otonomi fiskal daerah di Indonesia masih rendah, artinya daerah belum mampu membiayai pengeluaran rutinnya. Karena itu otonomi daerah bisa diwujudkan hanya apabila disertai keuangan yang efektif. Pemerintah daerah secara finansial harus bersifat independen terhadap pemerintah pusat dengan jalan sebanyak mungkin menggali sumber-sumber PAD (Radianto, 1997,42 ; dan A Halim, 2001, 348). Realitas hubungan fiskal antara daerah dan pusat, ditandai dengan tingginya kontrol pusat terhadap proses pembangunan daerah. Ini terlihat jelas dari rendahnya PAD terhadap total pendapatan dibandingkan dengan total subsidi yang didrop dari pusat. mengalami peningkatan dari Tahun ke tahun pada :

Tabel 1.1 Penerimaan pendapatan Asli daerah (PAD)

\begin{tabular}{|c|c|}
\hline Tahun & PAD \\
\hline 2010 & $39,054,813,602$ \\
\hline 2011 & $29,102,063,313$ \\
\hline 2012 & $27,840,607,088$ \\
\hline 2013 & $31,128,846,828$ \\
\hline 2014 & $41,174,930,611$ \\
\hline 2015 & $53,453,844,645$ \\
\hline
\end{tabular}

Sumber Data: Dispemda Kabupaten Bintuni.2016

Keleluasaan dalam usaha menggali sumber-sumber penerimaan tersebut, banyak daerah yang memikirkan bagaimana meningkatkan tarif pajak dan retribusi daerah serta obyek-obyek pajak dan retribusi yang baru. Hal ini menimbulkan keresahan di daerah, karena rakyat khawatir akan membayar pajak lebih banyak dibanding sebelum adanya otonomi daerah.

Dalam UU No. 91 tahun 2010 pasal 2 ayat (4) bahwa dengan Peraturan daerah dapat ditetapkan jenis pajak kabupaten/kota selain yang ditetapkan dalam ayat (2). Sedangkan dalam ayat (2) dinyatakan jenis-jenis pajak yaitu pajak hotel, restoran, hiburan, reklame, penerangan jalan, pengambilan bahan galian golongan $\mathrm{C}$, dan pajak parkir. Kenyataan ini berpotensi untuk mendorong pemerintah daerah saling berlomba dalam menerbitkan Peraturan Daerah (Perda) dengan mengesampingkan kriteria maupun prinsip perpajakan. Undang-Undang nomor 23 tahun 2004 dan Undang-Undang nomor 23 tahun 2014 yang sebenarnya 
dimaksudkan untuk mengurangi ketergantungan daerah terhadap pemerintah pusat, justru berimplikasi menciptakan horizontal imbalance, disamping mengurangi vertical imbalance (FX. Sugiyanto, 2000: 4).

Berdasarkan latar belakang diatas, maka yang menjadi tujuan penelitian ini adalah: (a) Untuk mengetahui dan menganalisis tingkat kemandirian fiskal Kabupaten Teluk Bintuni tahun 2010-2015; (b) Untuk mengetahui dan menganalisis pengaruh dari dari pajak, retribusi dan Tingkat Ekonomi secara simultan terhadap tingkat kemandirian daerah Kabupaten Teluk Bintuni; (c) Untuk mengetahui dan menganalisis pengaruh dari dari pajak, retribusi dan tingkat ekonomi secara pasial terhadap tingkat kemandirian daerah Kabupaten Teluk Bintuni.

Berkaitan dengan hakekat otonomi daerah mengenai pelimpahan wewenang pengambilan keputusan kebijakan, pengelolaan dana publik dan pengaturan kegiatan dalam penyelenggaraan pemerintah dan pelayanan masyarakat, maka peranan data keuangan daerah sangat dibutuhkan untuk mengidentifikasi sumber-sumber pembiayaan daerah serta jenis dan besar balanja yang harus dikeluarkan agar perencanaan keuangan dapat dilaksanakan secara efektif dan efisien. Data keuangan daerah yang memberikan gambaran statistik perkembangan anggaran dan realisasi, baik penerimaan maupun pengeluaran dan analisa terhadapnya merupakan informasi yang penting terutama untuk membuat kebijakan dalam pengelolaan keuangan daerah untuk melihat kemampuan dan kemandirian daerah (Yuliati, 2001) Secara konseptual, pola hubungan antara pemerintah pusat dan daerah harus dilakukan sesuai dengan kemandirian keuangan daerah dalam membiayai pelaksanaan pemerintahan dan pembangunan, walaupun pengukuran kemampuan keuangan daerah ini akan menimbulkan perbedaan.

Bertolak dari teori tersebut, karena adanya potensi sumber daya alam dan sumber daya manusia yang berbeda, akan terjadi pula perbedaan pola hubungan dan tingkat kemandirian antar daerah. Sebagai pedoman dalam melihat pola hubungan dengan kemandirian daerah (dari sisi keuangan) dapat dihitung dengan rumus sebagai berikut :

$$
\text { Rasio Kemandirian }=\frac{\text { Pendapatan Asli Daerah }}{\text { Bantuan Pemerinah Pusat/Propinsi }} \times 100 \%
$$


Tabel 1.2 Pola Hubungan dan Tingkat Kemampuan daerah

\begin{tabular}{|c|c|c|}
\hline $\begin{array}{c}\text { Kemampuan } \\
\text { Keuangan }\end{array}$ & $\begin{array}{c}\text { Tingkat Kemandirian } \\
(\%)\end{array}$ & Pola Hubungan \\
\hline Rendah Sekali & $0 \%-25 \%$ & Instruktif \\
\hline Rendah & $25 \%-50 \%$ & Konsultatif \\
\hline Sedang & $50 \%-75 \%$ & Partisipatif \\
\hline Tinggi & $75 \%-100 \%$ & Delegatif \\
\hline
\end{tabular}

Sumber :Halim (2002:189)

Abdul Halim, (2004), menjelaskan dalam konteks otonomi daerah di Indonesia, proses pengelolaan anggaran miliki implikasi yang sangat luas terhadap pelaksanaan berbagai kebijakan pemerintah daerah, baik secara ekonomis maupun politis. Setiap daerah memiliki masalah proporsi kebijakan keuangan yang berbeda, dengan mempertimbangkan berbagai faktor seperti kemampuan keuangan daerah, struktur sosial dan ekonomi penduduk, budaya, politis dan aturan yang berlaku dari pemerintah pusat.

Pajak merupakan hak prerogatif pemerintah berupa pungutan yang didasarkan pada undang-undang dan dapat dipaksakan kepada subyeknya tanpa batas yang langsung dapat ditunjukkan (Guritno, 2001, 181).

Retribusi adalah pemungutan daerah sebagai pembayaran atas jasa atau pemberian ijin tertentu yang khusus disediakan dan/atau diberikan oleh pemerintah daerah untuk kepentingan orang pribadi atau badan (UU nomor 91 tahun 2010) Retribusi daerah dibagi atas tiga golongan yaitu : (1) Retribusi Jasa Umum; (2) Retribusi Jasa Usaha, dan (3) Retribusi Perijinan Tertentu.

Perubahan dalam bentuk hubungan pemerintah pusat dengan pemerintah daerah dan implikasinya terhadap pengelolaan keuangan daerah telah melahirkan berbagai persepsi. Sementara pihak meragukan kemampuan daerah, baik dari segi kesiapan sumberdaya manusia maupun perangkat pendukungnya, sementara yang lain berpandangan bahwa saat pemerintah daerah bisa menunjukkan kemampuannya sebagai pelayan masyarakat dengan lebih baik dibanding sebelumnya. Ekses lain adalah keterbukaan atas informasi yang semakin luas sehingga kebijakan yang dikeluarkan oleh pemerintah daerah dapat diamati oleh masyarakat, terutama melalui peran media masa dan LSM (Abdul Halim, 2004). 
Keberhasilan suatu pembangunan dalam suatu daerah salah satunya dapat ditunjukkan dengan kemajuan ekonomi daerah tersebut (Todaro:2006). Untuk menilai pertumbuhan ekonomi digunakan tiga macam ukuran yaitu pertumbuhan output, pertumbuhan output per kapita, dan pertumbuhan output per pekerja.

Faktor-faktor yang mempengaruhi pertumbuhan ekonomi yaitu (Jhinghan, 2002): (a) Sumber Daya Alam (SDA); (b). Akumulasi Modal; (c). Organisasi; (d). Kemajuan Teknologi; (e). Pembagian Kerja dan Skala Produksi.

\section{Gambar 1.1. Model Penelitian}

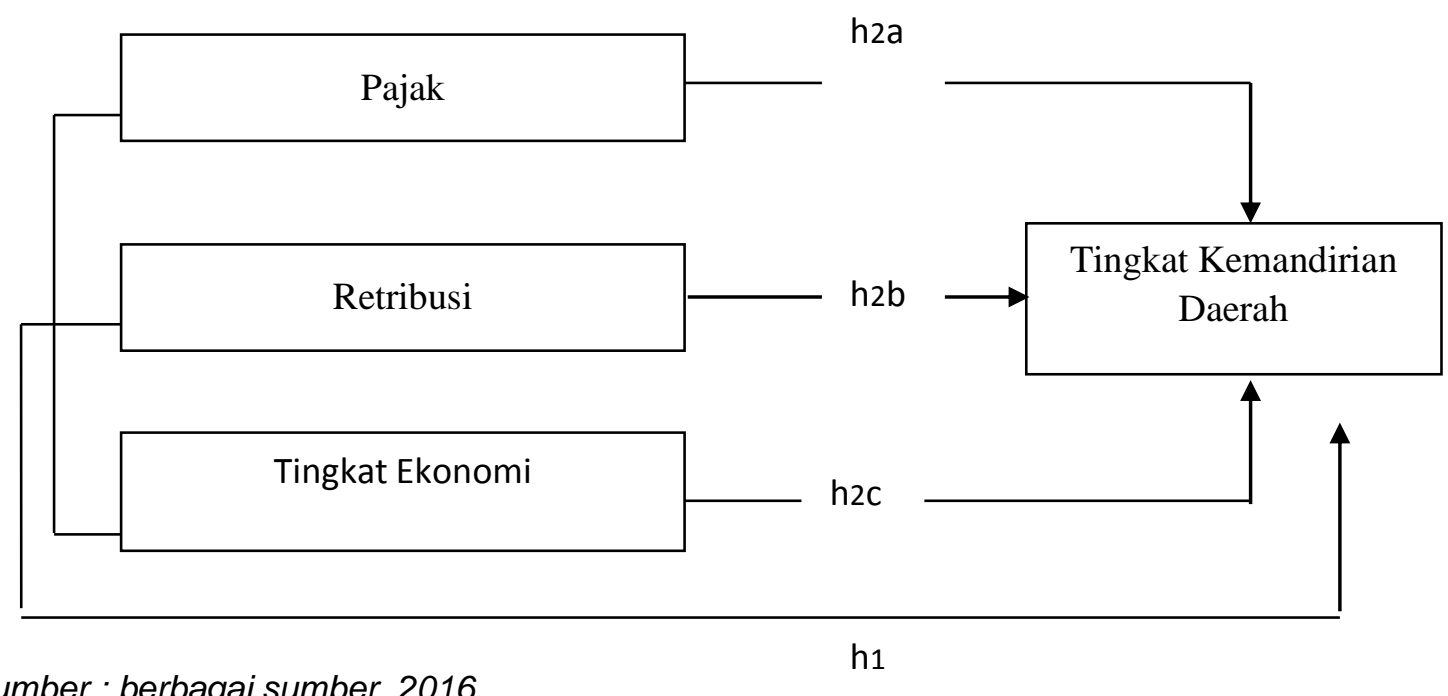

Sumber : berbagai sumber, 2016

\section{METODE PENELITIAN}

Dallam Penelitian ini penulis memakain metode analisis kualitatif adalah analisa yang berdasarkan data dan dinyatakan dalam bentuk uraian. Data ini merupakan data yang berupa informasi uraian dalam bentuk bahasa prosa kemudian dikaitkan dengan data lainnya untuk mendapatkan kejelasan atau menguatkan suatu gambaran yang telah ada. Sementara sumber data yang digunakan adalah data series tahun 2010 sampai dengan 2015.

Data yang diperlukan adalah sebagai berikut: (a) Data Realiasi Anggaran APBD Kabupaten Teluk Bintuni Tahun 2010 -2015; (b) Data PAD Kabupaten Teluk Bintuni Tahun 2010 -2015; (c) Untuk melihat tingkat ekonomi penulis menggunakan data PDRB Kabupaten Teluk Bintuni Tahun 2010-2015. Sementara metode pengumpulan data dalam penelitian ini dilakukan dengan studi kepustakaan. Studi pustaka adalah metode pengumpulan data yang dapat 
dilakukan dengan cara melakukan pengamatan data dari literature- literatur dan buku-buku yang mendukung.

Dalam penelitian ini pengumpulan data dilakukan dengan cara : (a) Data diperoleh dari Badan Pusat Statistik (BPS); (b) Laporan Keuangan Pemerintah Kabupaten Teluk Bintuni tahun 2005 -2014; (c) Data atau informasi yang diperoleh dari buku referensi, jurnal, majalah, surat kabar yang berkaitan dengan penelitian ini.

Tingkat kemandirian adalah ukuran yang menunjukan kemampuan keuangan pemerintah daerah dalam membiayai sendiri kegiatan pemerintah yang diukur dengan rasio Pendapatan Asli Daerah (PAD) terhadap jumlah bantuan pemerintah pusat dan pinjaman. Berikut ini formula yang di gunakan untuk mengukur tingkat kemandirian dari Litbang Depdagri ( 1991)

$$
\text { Rasio Kemandirian }=\frac{\text { Pendapatan Asli Daerah }}{\text { Dana Perimbangan }} \times 100 \%
$$

Kriteria untuk menetapkan kemandirian daerah dapat dikategorikan seperti Tabel berikut ini :

Tabel 1.3 Kriteria Penilaian Kemandirian

\begin{tabular}{|c|c|}
\hline $\begin{array}{c}\text { Presentase PAD Terhadap Dana } \\
\text { Perimbangan }\end{array}$ & $\begin{array}{c}\text { Kriterian } \\
\text { Kemandirian }\end{array}$ \\
\hline $0,00-10,00$ & Sangat Kurang \\
\hline $10,01-20,00$ & Kurang \\
\hline $20,01-30,00$ & Sedang \\
\hline $30,01-40,00$ & Cukup \\
\hline $40,01-50,00$ & Baik \\
\hline$>50,00$ & Sangat Baik \\
\hline
\end{tabular}

Sumber : Tim Litbang Depdagri - Fisipol UGM, 1991

\section{HASIL PENELITIAN}

Pertumbuhan PDRB, Berdasarkan sektor yang memiliki pertumbuhanpaling cepat di Kabupaten Teluk Bintuni jika di lihat dari Transportasi dan Pergudangan mencapai sebesar 14.10 persen sektor ini lebih memiliki laju pertumbuhan paling tinggi. Sedangkan pertumbuhan terendah yaitu Pertambangan dan Penggalian sebesar 1.17 persen. 


\section{Tabel 1.4}

\section{DRB Kabupaten Teluk Bintuni}

\begin{tabular}{|c|l|c|c|c|c|c|c|}
\hline Kategori & \multicolumn{1}{|c|}{ Lapangan Usaha/ndustry } & 2010 & 2011 & 2012 & 2013 & 2014 & 2015 \\
\hline A & Pertanian, Kehutanan, Dan Perikanan & $579,458.17$ & $563,858.74$ & $575,966.60$ & $591,711.61$ & $608,245.69$ & $624,779.77$ \\
\hline B & Pertambangan Dan Penggalian & $7,899,061.74$ & $7,997,270.99$ & $8,117,443.89$ & $8,384,970.03$ & $8,376,912.84$ & $8,368,855.65$ \\
\hline C & Industri Pengolahan & $9,283,651.52$ & $10,311,946.85$ & $10,653,934.46$ & $11,387,680.65$ & $11,819,536.13$ & $12,251,391.61$ \\
\hline D & Pengadaan Listrik Dan Gas & $20,162.00$ & 21927 & $23,786.00$ & $25,478.00$ & 271.72 & $(24,934.56)$ \\
\hline E & $\begin{array}{l}\text { Pengadaan Air, Pengelolaan Sampah, Limbah Dan } \\
\text { Daur Ulang }\end{array}$ & 467.24 & 471.73 & 478.53 & 487.21 & 497.66 & 508.11 \\
\hline F & Konstruksi & $201,976.34$ & $227,738.38$ & $246,934.51$ & $275,643.22$ & $292,857.73$ & $310,072.24$ \\
\hline G & $\begin{array}{l}\text { Perdagangan Besar Dan Eceran; Reparasi Mobil Dan } \\
\text { Sepeda Motor }\end{array}$ & $57,576.68$ & $60,397.00$ & $62,950.90$ & $66,217.93$ & $71,202.53$ & $76,187.13$ \\
\hline H & Transportasi Dan Pergudangan & $17,932.02$ & $19,931.03$ & $22,210.37$ & $24,788.84$ & $27,681.02$ & $30,573.20$ \\
\hline I & Penyediaan Akomodasi Dan Makan Minum & $4,246.34$ & $4,410.66$ & $4,688.24$ & $4,829.58$ & $5,021.16$ & $5,212.74$ \\
\hline J & Informasi Dan Komunikasi & $6,230.98$ & $6,287.65$ & $6,418.46$ & $6,848.25$ & $7,400.57$ & $7,952.89$ \\
\hline K & Jasa Keuangan Dan Asuransi & $20,237.40$ & $21,189.74$ & $22,654.67$ & $25,285.22$ & $26,938.48$ & $28,591.74$ \\
\hline L & Real Estat & $17,181.56$ & $18,349.27$ & $20,158.17$ & $21,983.07$ & $24,004.85$ & $26,026.63$ \\
\hline Iu,N & Jasa Perusahaan & 651.11 & 663.24 & 680.64 & 701.11 & 724.77 & 748.43 \\
\hline O & $\begin{array}{l}\text { Administrasi Pemerintahan, Pertahanan Dan Jaminan } \\
\text { Sosial Wajib }\end{array}$ & $209,071.70$ & $229,023.53$ & $258,001.65$ & $282,403.87$ & $305,658.30$ & $328,912.73$ \\
\hline P & Jasa Pendidikan & $35,433.23$ & $36,591.16$ & $38,220.21$ & $41,753.54$ & $45,750.15$ & $49,746.76$ \\
\hline Q & Jasa Kesehatan Dan Kegiatan Sosial & $10,402.14$ & $11,211.92$ & $11,953.78$ & $12,187.83$ & $12,653.69$ & $13,119.55$ \\
\hline R,S,T,U & Jasa Lainnya & 670.48 & 694.73 & 718.4 & 756.03 & 807.74 & 859.45 \\
\hline Produk Domestik Regional Bruto & $18,344,450.76$ & $19,510,255.88$ & $20,043,651.35$ & $21,128,502.77$ & $21,626,165.04$ & $22,123,827.31$ \\
\hline
\end{tabular}

Sumber ; Bps Kabupaten Teluk Bintuni,2015

Pertumbuhan Pajak, Tingkat pertumbuhan menggambarkan seberapa besar kemampuan pemerintah daerah dalam mempertahankan dan meningkatkan keberhasilannya yang telah dicapai dari periode ke periode berikutnya (Halim, 2001). Tingkat pertumbuhan pajak di Kabupaten Teluk Bintuni ditunjukkan dalam Tabel dan gambar berikut ini.

Tabel 1.5 Rasio Pertumbuhan Pajak Daerah Kabupaten Teluk BintuniTahun 2010-2015

\begin{tabular}{|c|c|c|c|}
\hline \multirow{2}{*}{ Tahun } & \multicolumn{2}{|c|}{ Pajak Daerah } & \multirow{2}{*}{ Rasio Pertumbuhan } \\
\cline { 2 - 3 } & Target & Realisasi & - \\
\hline 2010 & $956,000.000$ & $1,589,612.505$ & 68.53 \\
\hline 2011 & $11,985,000.00$ & $2,679,029.936$ & 256.76 \\
\hline 2012 & $10,250,000.000$ & $9,557,622.413$ & 25.62 \\
\hline 2013 & $10,250,000.00$ & $12,006,577.40$ & 2.94 \\
\hline 2014 & $12,525,000.00$ & $12,360,168.603$ & -22.88 \\
\hline 2015 & $11,535,000.000$ & $9,532,097.859$ & \\
\hline
\end{tabular}

Pertumbuhan Retribusi Daerah, Berdasarkan tabel diatas terlihat pertumbuhan dari realisasi penerimaan retribusi daerah cukup baik dari tahun ke tahun selama lima tahun dari tahun 2011-215. Pertumbuhan tahun $2011-2015$ adalah sebesar 122.63 persen. 
Tabel 1.6 Pertumbuhan Retribusi Daerah Kabupaten Teluk Bintuni

\begin{tabular}{|c|c|c|c|}
\hline \multirow{2}{*}{ Tahun } & \multicolumn{2}{|c|}{ Retribusi Daerah } & \multirow{2}{*}{$\begin{array}{c}\text { Rasio } \\
\text { Pertumbuhan }\end{array}$} \\
\cline { 2 - 3 } & Target & Realisasi & - \\
\hline 2010 & $4,535,175.000$ & $4,385,658.980$ & 11.02 \\
\hline 2011 & $6,318,000.00$ & $4,868,952.750$ & -10.70 \\
\hline 2012 & $6,323,000.000$ & $4,347,933.700$ & -2.25 \\
\hline 2013 & $7,265,000.00$ & $4,250,220.100$ & 122.63 \\
\hline 2014 & $10,185,000.00$ & $9,462,147.841$ & -77.92 \\
\hline 2015 & $5,665,000.000$ & $2,088,788.939$ & \\
\hline
\end{tabular}

Sumber : Data diolah,2016

Tranfer Pemerintah Pusat, Pada Tabel berikut ini digambarkan subsidi dari pemerintah pusat yang dialokasikan pada Kabupaten Teluk Bintuni sejak tahun 2010 sampai dengan tahun 2014.

Tabel 1.7 Daftar Transfer Pemerintah Pusat Kepada Kabupaten Teluk Bintuni Tahun 2010 S/D 2014

\begin{tabular}{|c|r|r|r|r|r|}
\hline Tahun & Bagi Hasil Pajak & Bukan Pajak & Dana Alokasi Umum & $\begin{array}{c}\text { Dana Alokasi } \\
\text { Khusus }\end{array}$ & $\begin{array}{c}\text { Jumlah Transfer dari } \\
\text { Pemerintah Pusat }\end{array}$ \\
\hline 2010 & 175.596 .809 .359 & 109.696 .438 .539 & 322.134 .591 .000 & 33.612 .900 .000 & 736.355 .319 .816 \\
\hline 2011 & 180.582 .067 .048 & 53.225 .312 .611 & 391.764 .890 .000 & 44.661 .500 .000 & 865.381 .128 .314 \\
\hline 2012 & 141.912 .150 .101 & 24.959 .541 .392 & 472.543 .967 .000 & 43.298 .340 .000 & 822.610 .947 .541 \\
\hline 2013 & 209.185 .851 .125 & 312.727 .348 .971 & 550.845 .412 .000 & 550.845 .412 .000 & 1.380 .905 .064 .720 \\
\hline 2014 & 192.729 .009 .061 & 246.040 .566 .590 & 576.627 .019 .000 & 576.627 .019 .000 & 1.458 .443 .859 .222 \\
\hline
\end{tabular}

Sumber Data : Data diolah. 2016

Target dan Realisasi PAD, Pajak dan Retribusi, Pada Tabel berikut ini digambarkan PAD Kabupaten Teluk Bintuni yang terdiri dari pajak, dan retribusi daerah sejak tahun 2010 sampai dengan tahun 2015.

Tabel 1.8 Target dan Realisasi PAD, Pajak dan Retribusi Daerah Kabupaten Bintuni Tahun 2010-2015

\begin{tabular}{|c|c|c|c|c|c|c|}
\hline \multirow{2}{*}{ Tahun } & \multicolumn{2}{|c|}{ PAD } & \multicolumn{2}{c|}{ Pajak Daerah } & \multicolumn{2}{c|}{ Retribusi Daerah } \\
\cline { 2 - 7 } & Target & Realisasi & Target & Realisasi & Target & Realisasi \\
\hline \multirow{2}{*}{2010} & 35.353 .175 .000 & $39,054,813.602$ & $956,000.000$ & $1,589,612.505$ & $4,535,175.000$ & $4,385,658.980$ \\
\hline
\end{tabular}


Jurnal Keuda Vol. 2 No. 3

ISSN 2477-7838

\begin{tabular}{|c|c|c|c|c|c|c|}
\hline \multirow{2}{*}{ Tahun } & \multicolumn{2}{|c|}{ PAD } & \multicolumn{2}{c|}{ Pajak Daerah } & \multicolumn{2}{c|}{ Retribusi Daerah } \\
\cline { 2 - 7 } & Target & Realisasi & Target & Realisasi & Target & Realisasi \\
\hline 2011 & 34.701 .800 .00 & $29,102,063.313$ & $11,985,000.00$ & $2,679,029.936$ & $6,318,000.00$ & $4,868,952.750$ \\
\hline 2012 & 33.600 .000 .000 & $27,840,607.088$ & $10,250,000.000$ & $9,557,622.413$ & $6,323,000.000$ & $4,347,933.700$ \\
\hline 2013 & 20.000 .000 .000 & $31,128,846.83$ & $10,250,000.00$ & $12,006,577.40$ & $7,265,000.00$ & $4,250,220.100$ \\
\hline 2014 & 32.425 .000 .000 & $41,174,930.611$ & $12,525,000.00$ & $12,360,168.603$ & $10,185,000.00$ & $9,462,147.841$ \\
\hline 2015 & 37.388 .311 .600 & $53,453,844.645$ & $11,535,000.000$ & $9,532,097.859$ & $5,665,000.000$ & $2,088,788.939$ \\
\hline
\end{tabular}

Sumber : Dispemda Kabupaten Teluk Bintuni,2016

Belanja Tidak Langsung dan Belanja Langsung, Belanja tidak langsung dan belanja langsung daerah Kabupaten Teluk Bintuni dari tahun 2010-2014 dapat dilihat pada Tabel berikut :

Tabel 1.9 Belanja Tidak Langsung Dan Belanja Langsung Daerah Kabupaten Teluk Bintnui, Tahun 2010-2014

\begin{tabular}{|c|c|c|c|c|}
\hline \multicolumn{3}{|c|}{ Belanja Tidak Langsung } & \multicolumn{2}{c|}{ Belanja Langsung } \\
\hline Tahun & Target & Realisasi & Target & Realisasi \\
\hline 2010 & $165,228,465,457.00$ & $165,640,935,457.00$ & $769,755,494,740.00$ & $752,193,381,385.00$ \\
\hline 2011 & $131,855,326,949.22$ & $135,942,848,530.22$ & $671,624,471,835.76$ & $735,556,109,535.76$ \\
\hline 2012 & $180,936,429,247.02$ & $193,777,025,985.02$ & $721,129,646,962.98$ & $746,807,255,662.98$ \\
\hline 2013 & $234,506,742,259.50$ & $251,860,540,653.50$ & $832,162,661,380.50$ & $906,566,422,020.50$ \\
\hline 2014 & $262,446,207,463.77$ & $297,837,662,811.26$ & $936,681,936,407.33$ & $1,123,160,019,481.86$ \\
\hline
\end{tabular}

Sumber : Dispemda Kabupaten Teluk Bintuni,2016

\section{PEMBAHASAN}

Kemandirian Daerah, Tingkat kemandirian fiskal adalah ukuran yang menunjukan kemampuan suatu daerah mampu membiayai sendiri kegiatan pemerintahan, pembangunan dan pelayanan kepada masyarakat, yang di ukur dengan rasio pendapatan daerah terhadap jumlah bantuan pemerintah pusat dan pinjaman.

Berdasarkan hasil penelitian penulis dengan menggunakan data-data sekunder yang di peroleh dari Dispemda Kabupaten Teluk Bintuni berupa data ringkasan perubahan APBD, maka tingkat kemandirian fiskal daerah Kabupaten Teluk Bintuni dapat dilihat pada tabel berikut ini: 
Jurnal Keuda Vol. 2 No. 3

ISSN 2477-7838

Tabel 1.10 Rasio Kemandirian Keuangan Daerah Kabupaten Teluk Bintuni Tahun 2010-2015

\begin{tabular}{|c|c|c|c|c|}
\hline Tahun & PAD & Dana Perimbangan & Rasio Kemandirian & Kriteria \\
\hline 2010 & $39,054,813,602$ & $736,355,319,816$ & 5.30 & Sangat Kurang \\
\hline 2011 & $29,102,063,313$ & $865,381,128,314$ & 3.36 & Sangat Kurang \\
\hline 2012 & $27,840,607,088$ & $822,610,947,541$ & 3.38 & Sangat Kurang \\
\hline 2013 & $31,128,846,828$ & $1,380,905,064,720$ & 2.25 & Sangat Kurang \\
\hline 2014 & $41,174,930,611$ & $1,458,443,859,222$ & 2.82 & Sangat Kurang \\
\hline 2015 & $53,453,844,645$ & $1,667,984,991,599$ & 3.20 & Sangat Kurang \\
\hline \multicolumn{3}{|c|}{ Rata-rata } & 3.39 & \\
\hline
\end{tabular}

Sumber : Data di olah, 2016

Berdasarkan tingkat rasio kemandirian fiskal pada tabel 4.1 di atas, rata-rata tingkat kemandirian Kabupaten Teluk Bintuni selama periode tahun anggaran 2010-2015 adalah sebesar 3.39\%, sehingga di klafikasikan menurut kriteria penilaian kemandirian keuangan daerah Kabupaten Teluk Bintuni dengan tingkat kemandirian fikal daerah sangat kurang. Hal ini menunjukan bahwa Kabupaten Teluk Bintuni selama periode tahun anggaran 2010-2015 memiliki ketergantungan tinggi terhadap bantuan pemerintah pusat melalui dana perimbangan, dimana peran pemerintah pusat lebih dominan dari pada kemandirian pemerintah daerah. Rasio kemandirian masih rendah menunjukan pada sumber penerimaan daerah masih kurang maksimal. Hal ini di karenakan masih relative kurang PAD yang dapat di gali oleh pemerintah daerah, dana perimbangan terdiri dari : bagi hasil pajak/bukan pajak, DAU,DAK dan bantuan provinsi. Untuk mengatasi hal tersebut, pemerintah daerah harus dapat mengoptimalkan penerimaan dari potensi pendapatan yang telah ada, inisiatif, kreatifitas dan kemauan daerah sangat di perlukan dalam meningkatkan PAD. Pemerintah daerah harus mencari jalan yang dapat memungkinkan mengatasi kekurangan pembiayaan, hal ini memerlukan kreatifitas dari aparat pelaksanaan keungan daerah untuk mencari sumber-sumber pembiayaan dengan pihak swasta dan program peningkatan PAD. Walaupun tingkat kemandirian keuangan Kabupaten Teluk Bintuni relative rendah, akan tetapi dari tahun ke tahun memiliki kecenderungan yang selalu naik. Hal ini karena penerimaan pendapatan asli daerah Kabupaten Teluk Bintuni sejak tahun 2010 hingga 2015 rata-rata sebesar 3.39 persen. 


\section{Gambar 1.3 Persentase Kemandirian Daerah Kabupaten Teluk Bintuni}

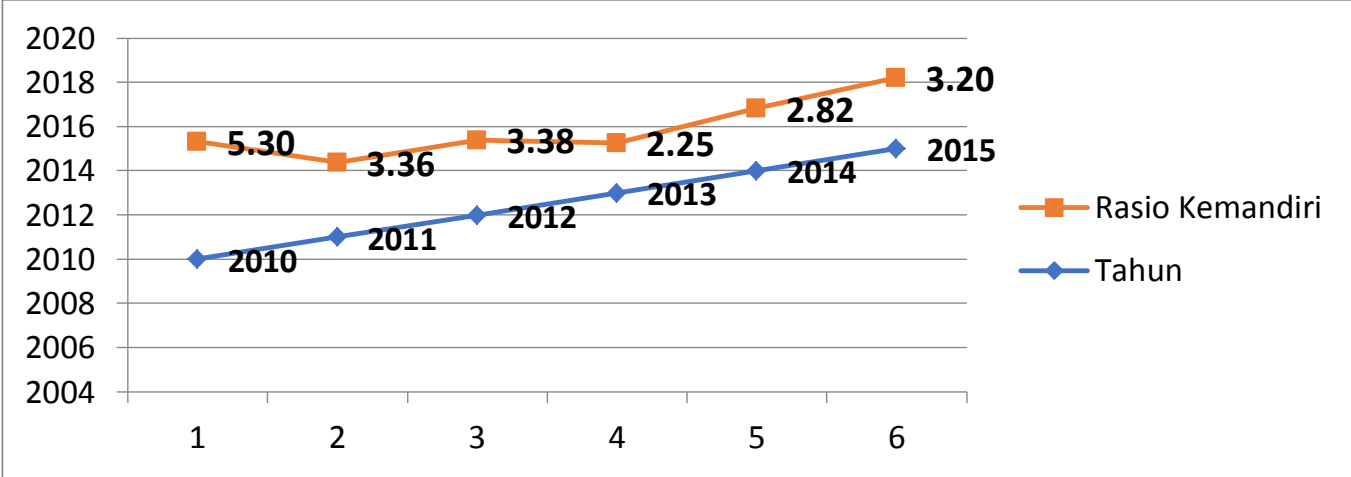

Sumber : Data diolah,2016

Kemandirian fiskal Kabupaten Teluk Bintuni dari tahun 2011-2014, dapat dilihat pada tahun 2010 yaitu 5.30 dan pada tahun 2015 yaitu 3.20 persen. Hal ini menujukan bahwa pemerintah Kabupaten Teluk Bintuni telah berusaha meningkatkan pendapatan asli daerah, dengan tujuan agar mampu mewujudkan kemandirian daerah yang lebih maksimal. Menurut Susilo dan Adi (2007) peningkatan PAD dalam era otonomi berpengaruh pada tingkat kemandirian, karena dengan meningkatnya PAD akan meningkatkan rasio kemandirian.

Dalam kategori kemampuan keuangan kurang dengan pola hubungan instruktif yaitu peranan pemerintah pusat sangat dominan dari pada daerah, hal ini dapat dilihat dari rasio kemandirian yang dihasilkan masih antara 0-25 \%. Rasio kemandirian yang masih rendah mengakibatkan kemampuan keuangan daerah Kabupaten Teluk Bintuni dalam membiayai pelaksanaan pemerintahan dan pembangunan masih sangat terrgantung pada penerimaan dari pemerintah pusat. Rasio kemandirian yang masih rendah dapat disebabkan pada sumber penerimaan daerah dan dasar pengenaan biaya, tampaknya Pendapatan Asli Daerah masih belum dapat diandalkan bagi daerah untuk otonomi daerah, karena relatif rendahnya basis pajak / retribusi yang ada di daerah dan kurangnya pendapatan asli daerah yang dapat digali oleh pemerintah daerah. Hai ini dikarenakan sumber-sumber potensial untuk menambah Pendapatan Asli Daerah masih dikuasai oleh pemerintah pusat. Sedangkan untuk basis pajak yang cukup besar masih dikelola oleh pemerintah pusat, yang di dalam pemungutan/pengenaannya berdasarkan undang-undang/peraturan pemerintah, dan daerah hanya menjalankan serta akan menerima bagian dalam bentuk dana perimbangan. Dana perimbangan itu sendiri terdiri dari : Bagi Hasil Pajak, Bagi Hasil Bukan Pajak/SDA, DAU, DAK, penerimaan lainnya. Untuk mengatasi hal tersebut, pemerintah daerah harus mampu mengoptimalkan penerimaan dari 
potensi pendapatannya yang telah ada. Inisiatif dan kemauan pemerintah daerah sangat diperlukan dalam upaya meningkatkan PAD. Pemerintah daerah harus mencari alternatif-alternatif yang memungkinkan untuk dapat mengatasi kekurangan pembiayaannya, dan hal ini memerlukan kreaitifitas dari aparat pelaksana keuangan daerah untuk mencari sumber-sumber pembiayaan baru baik melalui program kerjasama pembiayaan dengan pihak swasta dan juga program peningkatan PAD misalnya pendirian BUMD sektor potensial. Rendahnya rasio kemandirian daerah di Kabupaten Teluk Bintuni sama halnya dengan penelitian yang di lakukan oleh Ratna Sholikhah di Kabupaten Wonogiri hasil penetian menujukan bahw, rasio kemampuan keuangan daerah tergolong rendah dan mempunyai pola hubungan instruktif. Kemampuan Keuangan Daerah berpengaruh negatif tetapi tidak signifikan terhadap Pertumbuhan ekonomi (growth), artinya semakin tinggi tingkat kemampuan keuangan daearah tidak akan mengurangi tingkat pertumbuhan ekonomi. Kemandirian Daerah berpengaruh positif dan signifikan, artinya semakin tinggi rasio kemandirian daerahnya maka akan menambah tingkat pertumbuhan ekonomi Ini berarti bahwa tingkat kemampuan keuangan Kabupaten Wonogiri masih rendah dalam melaksanakan otonominya yang berarti kemampuan Pemerintah Kabupaten Wonogiri dalam memenuhi kebutuhan dana untuk penyelenggaraan tugastugas Pemerintahan, Pembangunan dan Pelayanan Sosial masyarakat masih relative rendah meskipun dari tahun ke tahun mengalami kenaikan dan penurunan.

\section{Pengaruh Pajak, Retribusi, dan Tingkat Ekonomi Secara Simultan Terhadap}

Kemandirian Daerah, Untuk mengukur seberapa besar pengaruh antara pajak, retribusi dan tingkat ekonomi, berdasarkan hasil analisis regresi berganda dapat nilai F statistik sebesar 9.327 dan F tabel sebesar $4.534(0.05,4,6)$ dengan tingkat signifikan di atas 0,05 yaitu 0.098 dengan demikian disimpulkan bahwa dalam model tersebut, variabel-variabel independen secara keseluruhan tidak mempunyai pengaruh yang signifikan terhadap kemandirian fiskal.

Berdasarkan hasil simultan variabel yaitu pajak, retribusi dan tingkat ekonomi tidak memberikan pengaruh besar terhadap tingkat kemandirian fiskal, namun pengaruh yang di berikan sangat sedikit sehingga untuk memenuhi kebutuhan pada daerah masih di butuhkan dana perimbangan untuk memenuhi kegiatan pemerintahan di Kabupaten Teluk Bintuni. (Suparmoko, 2002) Potensi ekonomi daerah merupakan kemampuan ekonomi yang ada di daerah yang mungkin dan layak dikembangkan sehingga akan terus berkembang menjadi 
sumber kehidupan rakyat setempat bahkan dapat menolong perekonomian secara keseluruhan untuk berkembang dengan sendirinya dan berkesinambungan.

\section{Pengaruh Pajak, Retribusi dan Tingkat Ekonomi secara parsial terhadap}

Kemandirian Daerah, Berdasarkan hasil analisis regresi berganda dapat dilihat uji t hitung pada variabel pajak X1 memilki koefisien regresi 1.086, varibel retribusi daerah memliki koefisien regresi X2 : 0.885, Varibel memiliki koefisien regresi Tingkat Ekonomi X3 : 0.345 di bandingkan dengan t tabel $2.447(0.05,6)$ maka nilai t hitung lebih kecil dari nilai t tabel. Hal ini berarti bahwa varibel pajak,retribusi daerah dan PDRB tidak berpengaruh positif dan signifikan terhadap tingkat kemandirian fiskal di Kabupaten Teluk Bintuni, dengan tingkat signifikan $0.05<$ X1 $0.391, \mathrm{X} 20.469 \times 3$ 0.763. sehingga hipotesis $(\mathrm{Ho})$ di terima dengan hipotesis alternative $(\mathrm{Hi}$ ) di tolak dengan kata lain variabel independen atau variabel bebas tidak berpengaruh positif dan signifikan terhadap variabel dependen $Y$ kemandirian fiskal.

Secara umum pertumbuhan ekonomi dapat diartikan sebagai perkembangan kegiatan dalam perekonomian yang menyebabkan barang dan jasa yang diproduksi dalam masyarakat bertambah dan kemakmuran masyarakat meningkat. Peningkatan pajak dan retribusi harus berdampak pada tingkat ekonomi daerah. Sidik (2002) dalam Harianto dan Adi (2007) menegaskan bahwa keberhasilan peningkatan PAD hendaknya tidak hanya diukur dari jumlah yang diterima, tetapi juga diukur dengan perannya untuk mengatur perekonomian masyarakat agar dapat lebih berkembang, yang pada gilirannya dapat meningkatkan kesejahteraan masyarakat di daerah. Daerah yang pertumbuhan ekonominya positif mempunyai kemungkinan mendapatkan kenaikan PAD. Dari perspektif ini seharusnya Pemerintah Kabupaten Teluk Bintuni lebih berkonsentrasi pada pemberdayaan kekuatan ekonomi lokal untuk menciptakan pertumbuhan ekonomi daripada sekedar mengeluarkan produk perundangan terkait dengan pajak ataupun retribusi .

Peningkatan pajak, retribusi dan tingkat ekonomi di Kabupaten Teluk Bintuni secara signifikan menunjukkan kemampuan daerah dalam memenuhi kebutuhannya serta memakmurkan masyarakatnya. Masyarakatlah yang kemudian dapat merangsang peningkatan ekonomi regional dengan melakukan aktifitas investasi maupun belanja. Kemandirian keuangan menjadi hal yang sangat penting bagi daerah di Kabupaten Teluk Bintuni terutama terkait dengan sumbangan keuangan daerah terhadap pertumbuhan ekonomi daerah itu sendiri. 
Dilihat dari penelitian terdahulu yang dilakukan Dwirandra (2006), menunjukkan bahwa semakin tinggi rasio kemandirian keuangan daerah berarti tingkat ketergantungan daerah terhadap bantuan pihak ekstern (terutama pemerintah pusat dan pemerintah propinsi) semakin rendah, demikian pula sebaliknya. Kurangnya pengaruh pajak dan retribusi di Kabupaten Teluk Bintuni ini juga menggambarkan tingkat partisipasi masyarakat dalam pembangunan daerah masih rendah ini berarti partisipasi masyarakat dalam membayar pajak dan retribusi daerah yang merupakan komponen PAD. Hal ini menunjukkan rendahnya tingkat kemampuan keuangan pada pemerintahan kabupaten Teluk Bintuni dalam membiayai sendiri kegiatan kepemerintahan, pembangunan, dan pelayanan kepada masyarakat. Besarnya penerimaan pajak dan retribusi daerah sebenarnya menunjukkan pemerintah daerah mengandalkan penerimaan pajak dan retribusi sebagai sumber penerimaan $P A D$, yang nantinya digunakan untuk membiayai pembangunan daerah. Penerimaan yang tinggi dari pajak dan retribusi daerah menunjukkan pemerintah daerah yakin dapat menggali potensi daerah dengan maksimal sehingga pendapatan pemerintah daerah yang berupa pajak akan meningkat. Namun, dari penerimaan pajak dan retribusi daerah sebagai komponen utama PAD dengan nilai yang masih rendah, menunjukkan pemerintah kabupaten Teluk Bintuni kurang yakin dapat menggali potensi daerah, sehingga PAD yang bersumber dari pajak dan retribusi tidak besar. Kondisi inilah yang mendorong pemerintah daerah kurang berani dalam menetapkan penerimaan pajak yang tinggi dalam sumber APBD. Dengan kata lain, pemerintah daerah Kabupaten Teluk Bintuni tidak yakin pajak yang diterima oleh daerahnya dapat diandalkan sebagai salah satu sumber pembiayaan pembangunan daerah di APBD, sehingga PAD yang dianggarkan rendah.

Daerah yang memiliki tingkat pertumbuhan PAD yang positif mempunyai kemungkinan untuk memiliki tingkat Ekonomi yang lebih baik. Tingkat Ekonomi merupakan salah satu ukuran bagi kemakmuran suatu daerah, Tingkat Ekonomi yang tinggi cenderung mendorong naiknya tingkat konsumsi yang selanjutnya menimbulkan insentif bagi diubahnya struktur produksi (pada saat pendapatan meningkat, permintaan akan barang-barang manufaktur dan jasa pasti akan meningkat lebih cepat daripada permintaan akan produk-produk pertanian (Todaro, 2000). Semakin tinggi pendapatan seseorang maka akan semakin tinggi pula kemampuan seseorang untuk membayar (ability to pay) berbagai pungutan yang ditetapkan oleh pemerintah. Pada tingkat distribusi pendapatan tertentu yang tetap, semakin tinggi Tingkat ekonomi di Kabupaten Teluk Bintuni, semakin besar 
pula kemampuan masyarakat daerah tersebut untuk membiayai pengeluaran rutin dan pengeluaran pembangunan pemerintahannya. Maka dapat dikatakan bahwa semakin tinggi tingkat ekonomi suatu daerah, semakin besar pula potensi sumber penerimaan daerah tersebut, sehingga kemampuan masyarakat untuk membayar pajak yang meningkat. Tinggi rendahnya tingkat ekonomi suatu daerah dapat dipengaruhi oleh banyak hal diantaranya adalah banyaknya atau sedikitnya lapangan pekerjaan, perbedaan UMR tiap daerah, dan tingkat kemajuan dari daerah itu sendiri. Jika pemerintah daerah menetapkan anggaran belanja pembangunan lebih besar dari pengeluaran rutin, maka kebijakan ekspansi anggaraan daerah ini akan mendongkrak pertumbuhan ekonomi daerah (Saragih, 2003). Dalam penelitiannya Lin dan Liu (2000) menyatakan bahwa pemerintah daerah perlu untuk meningkatkan investasi modal guna meningkatkan pertumbuhan ekonomi daerah. Penelitian yang dilakukan oleh Adi (2006) membuktikan bahwa belanja modal mempunyai pengaruh positif terhadap pertumbuhan ekonomi Alokasi belanja modal untuk penunjang perekonomian, akan mendorong tingkat produktifitas penduduk. Pada gilirannya hal ini dapat meningkatkan tingkat ekonomi masyarakat secara umum yang tercermin dalam pendapatan per kapita.

\section{KESIMPULAN DAN SARAN}

\section{Kesimpulan}

Kemandirian keuangan daerah Kabupaten Teluk Bintuni masih sangat kurang. Hal ini menunjukan bahwa Kabupaten Teluk Bintuni selama periode tahun anggaran 2010-2015 memiliki ketergantungan tinggi terhadap bantuan pemerintah pusat melalui dana perimbangan, dimana peran pemerintah pusat lebih dominan dari pada kemandirian pemerintah daerah. penerimaan daerah dan dasar pengenaan biaya, tampaknya Pendapatan Asli Daerah masih belum dapat diandalkan bagi daerah untuk otonomi daerah, karena relatif rendahnya basis pajak / retribusi yang ada di daerah dan kurangnya pendapatan asli daerah yang dapat digali oleh pemerintah daerah.

Secara simultan tidak terdapat pengaruh Pajak, Retribusi dan Tingkat Ekonomi, terhadap tingkat kemandirian daerah. Secara parsial (a) Variabel pajak tidak berpengaruh terhadap kemandirian daerah di Kabupaten Teluk Bintuni hal ini di sebabkan karean t hitung lebih kecil dari t tebal; (b) Berdasarkan hasil analisis regresi dapat di simpulkan variabel retribusi tidak berpengaruh terhadap kemandirian daerah di Kabupaten Teluk Bintuni hal ini di sebabkan karean t hitung 
lebih kecil dari t tebal; (c) Tingkat Ekonomi tidak berpengaruh terhadap kemandirian daerah di Kabupaten Teluk Bintuni hal ini di sebabkan karean t hitung lebih kecil Dari t tabel

\section{Saran}

Pemerintah daerah Kabupaten Bintuni perlu mingkatkan potensi yang ada pada daerah seperti PAD dan PDRB supaya mendukung kemandirian fiskal. Pemerintah Kabupaten Bintuni diharapkan berupaya untuk lebih meningkatkan PAD nya dengan mengoptimalkan pengelolaan sumber daya dan memperluas sektor-sektor yang berpotensi menambah PAD, sehingga ketergantungan pendapatan dari Pemerintah Pusat bisa semakin berkurang. Pemerintah Kabupaten Bintuni agar lebih proporsional di dalam mengalokasikan belanjanya, yakni mengurangi belanja operasional dan meningkatkan belanja modal.

\section{DAFTAR PUSTAKA}

Badan pusat statistic teluk bintuni, Kabupaten teluk bintuni dalam angka,PDRB Tahun $2010-2015$.

Bahrul Ulum Rusydi 2010, Analisis Determinan Kinerja Keuangan Pemerintah Daerah Dan Deteksi llusi Fiskal (Studi Kasus Provinsi Di Indonesia Tahun 2005-2008) Skripsi Fakultas Ekonomi Universitas Diponegoro Semarang

Dinas Pendapatan Daerah Kabupaten Teluk Bintuni; Data PAD, Dana Perimbangan Tahun 2010-2015.

Dori Saputra 2008,Analisis Kemandirian Dan Efektivitas Keuangan Daerah Pada Kabupaten Dan Kota Di Propinsi Sumatera Barat.Jurnal Program Studi Akuntansi Fakultas Ekonomi Universitas Negeri Padang 2014

Dina Apriana dan Rudy Suryanto 2010, Analisis Hubungan Antara Belanja Modal, Pendapatan Asli Daerah, Kemandirian Daerah Dan Pertumbuhan Ekonomi Daerah (Studi Pada Kabupaten Dan Kota Se Jawa-Bali)

Ervina Anwar, Anderson Kumenaung, dan George Kawung, Analisis Kemandirian Fiskal Tahun 2010-2012 Daerah Kabupaten/Kota Provinsi Sulawesi Utara. Jurnal Berkal Efisiensi IEP_ FEB Unsrat Manado.

Hadi Sasana 2006, Analisis Kemandirian Fiskal Dilihat Dari Sektor-Sektor Ekonomi Daerah (Studi Kasus Di Kabupaten Klaten ) Jurrnal Ekonomi dan bisnis Fakultas Undip Semarang Vol.1 No.2 Oktober 2006.

Hadi Sasana 2011, Analisis Determinan Belanja Daerah Di Kabupaten/Kotaprovinsi Jawa Barat Dalam Era Otonomi Dan Desentralisasi Fiskal. Jurnal Bisnis dan Ekonomi JBE Fakultas Ekonomi Diponogoro Semarang Vol.18. No1 2011. 
Joko Pramono 2014, Analisis Rasio Keuangan Untuk Menilai Kinerja Keuangan Pemerintah Daerah (Studi Kasus Pada Pemerintah Kota Surakarta) Jurnal STIE AMA Salatiga

Joko Tri Haryanto 2005, Analisa Data Alokasi Umum (Dau) Kaitannya Dengan Penciptaan Kemandirian Daerah Di Era Otonomi : Studi Kasus 30 Propinsi Di Indonesia. Jurnal Simposium Riset Ekonomi II Surabaya, 23-24 November 2005

Kuncoro Thesaurianto 2007, Analisis Pengelolaan Keuangan Daerah Terhadap Kemandirian Daerah. Tesis Program Pasca Sarjana Universitas Diponogoro Semarang.

Nurjanna Ladjin 2008, Analisis Kemandirian Fiskal Di Era Otonomi Daerah (Studi Kasus Di Propinsi Sulawesi Tengah). Tesis Program PascaSarjana Universitas Diponogoro Semarang.

Nely Aulia 2014, Hubungan Desentralisasi Fiskal Terhadap Pertumbuhan Ekonomi, Tingkat Kemiskinan, Dan Kesenjangan Pendapatan Kabupaten/Kota Di Provinsi Jawa Tengah Tahun 2012. Tesis Jurusan Ekonomi Pembangunan, Fakultas Ekonomi, Universitas Negeri Semarang, Indonesia.

Ratna sholikhah 2011, Analisis kemampuan kemandirian keungan daerah dan pengaruhnya terhadap pertumbuhan ekonomi kabupaten wonogiri tahun anggaran 2000-2009. Skripsi Fakultas Ekonomi Sebelas Maret Surakarta.

Riswanda Imawan, Agus Wahyudin 2014, Analisis Kemandirian Keuangan Daerah Provinsi Jawa Tengah Tahun Anggaran 2010-2012. Jurnal Jurusan Akuntansi, Fakultas Ekonomi, Universitas Negeri Semarang, Indonesia

Republik Indonesia, Undang-Undang Nomor 22 Tahun 1999 tentang Pemerintah Daerah.

, Undang-Undang Nomor 25 Tahun 1999 tentang Perimbangan Keuangan Antara Pemerintah Pusat dan Daerah.

Undang-Undang Nomor 34 Tahun 2000 tentang Perubahan Atas Undang-Undang Nomor 18 Tahun 1997 tentang Pajak Daerah dan Retribusi Daerah.

Peraturan Pemerintah Nomor 84 Tahun 2001 tentang Perubahan Atas Peraturan Pemerintah Nomor 104 Tahun 2000 tentang Dana Perimbangan.

Taryoko 2016, Analisis Faktor-Faktor Yang Mempengaruhi Kemandirian Keuangan Daerah Di Daerah Istimewa Yogyakarta Periode 2006-2013. Skripsi Program Studi Pendidikan Ekonomi Fakultas Ekonomi Universitas Negeri Yogyakarta

Pudji supratjitno 2003, Analisis factor-faktor yang mempengruhi kemandirian fiskal di daerah ( Studi Kasus di Kabupaten Banjarmasih. Tesis Program Pasca Sarjana Universitas Diponogor Semarang. 